\title{
Effectiveness of Storytelling on Reading Comprehension and Written Production of Indigenous Language (Igbo) Learners in Primary Schools in Ebonyi State, Nigeria
}

\author{
Nwigwe Nwakaego \\ Department of Arts and Social Science Education \\ Faculty of Education, Ebonyi State University, Abakaliki
}

\begin{abstract}
The study examined the effectiveness of storytelling aloud on the reading comprehension and written production of indigenous language (Igbo) learners at the primary schools in Ebonyi State, Nigeria. The study adopted a pretest-posttest, control group, quasi-experimental design. Two research questions guided the study. The sample was 100 primary five (5) pupils selected from the two public primary schools purposively. The two schools were assigned to experimental and control groups respectively and intact classes were used. Each group consisted of fifty (50) pupils in each of the respective schools. The instrument for data collection was an achievement test, indigenous stories and reading comprehension. The instrument was validated by three (3) experts in Igbo language and measurement and evaluation experts from Ebonyi State University. The reliability of the test was determined by pilot testing and it yielded a reliability coefficient of 0.80 . The data analyses were done using mean and standard deviation. The results showed that the experimental group performed better than the control group in both tests of reading comprehension and written production in Igbo language and were improved by the teacher's use of storytelling technique. Based on the findings, the following recommendations were made; that curriculum planners should include storytelling in the reading and writing components of Igbo curriculum in the primary schools; that Igbo language teachers should be encouraged to use storytelling technique in the teaching of reading comprehension and written production in Igbo language.
\end{abstract}

Keywords: Storytelling technique, reading comprehension, written production, Igbo language, performance.

DOI: $10.7176 / \mathrm{JEP} / 12-23-05$

Publication date:August $31^{\text {st }} 2021$

\section{Introduction}

Reading is one of the four basic communication skills, others being; listening, speaking and writing. Obanya (2002:180) defines reading as "interpreting written language and translating it into words and sentences that convey thought and ideas". The individual who reads well has a means for widening mental horizons and for multiplying opportunities of success (Satija, 2003). It is one of the most important factors of human accomplishment. The ability to read is an essential skill for students to master because information is presented in text throughout the world. Reading equally enhances scholastic success which can be manifested in writing.

Writing on the other hand is undoubtedly the most difficult of all the language skills and competent writing is frequently regarded as the last language skill to be acquired. Unfortunately, these important and fundamental language skills are not properly taught by teachers of Igbo language in primary schools in Ebonyi State. Most Igbo learners are often unable to read efficiently, and fully comprehend a written text, and they are unable to write intelligibly. Majority of Igbo students learn to decode but a large number of them experience serious problems with comprehension. This has grossly affected their performance in both internal and external examinations in majority of schools in Ebonyi State Nigeria.

Igbo Language is the supreme expression of the cultural heritage of the people of the South East, Nigeria. It is one of the three major Nigerian indigenous language approved by the Federal Government to be taught as a mother tongue or language of the immediate environment (Federal Republic of Nigeria,(2014). Igbo Language is learned at home, schools, colleges and tertiary institutions.

Classroom observations by the researcher showed that many factors do not allow Igbo learners to be committed or engaged in the learning process. These factors are connected with lack of vocabulary, monotonous lessons or lack of meaningful activities.. Consequently, students' participation in Igbo language class was limited as well as their learning process. There is a need to adopt and adapt teaching approaches that provide opportunities to improve students' literacies in Igbo language.

Many researchers such as Mokhtar et al (2010) and Al-Mansour (2011), and Oduolowu \& Oluwa Kemi (2014) recommended that traditional concepts related to teaching reading should be substituted by more innovative ones. Among those innovative techniques is storytelling which is one of the entertaining technique used to develop student's literacy skills. Teaching through storytelling dates back thousands of years (Kosa, 2009).

The importance of storytelling in education can hardly be over emphasized. According to Coulter, Michael 
\& Poyner (2008), storytelling offers much more than casual entertainment within academic settings. Instead, storytelling is a tool that helps students understand the world around them. Storytelling enables students to visualize themselves in similar situations as the character of the story (Combs \& Beach, 1994). Harris (2008) posits that stories allows us to see similarities in our experience even when we are divided by cultural differences. In addition, stories makes learning more fun and help students remember relevant materials (Frisch \& Saunders, 2009). Powell \& Murray (2012) note that when material is presented in a story format rather than traditional textbook format, students' comprehension of difficult theories and concepts improves and grades improve.

Storytelling is one of the oldest methods of communicating ideas and images (Mello, 2001). In the traditional African societies, young children were told stories by their parents, grandparents, uncles and aunts. According to Emenanjo (1977); folktales played a very important role in the community life of the Igbos in particular and Nigerians in general. Although the stories were unwritten, they have been passed down from generations without losing their originality. As important as storytelling is to the education of young children, it is not accorded adequate attention in primary schools. The little period of literature in Igbo Language in the school-time table for example, the teachers see it as a free period when they will do "other important things" due to lack of knowledge of the vital role of the subject (storytelling) to the lives of the children in primary school level. Teachers usually tell the children to go outside under a tree and tell stories which the teacher will not even be there to monitor or supervise (Nwigwe, 2016).

It has been observed that children spend more time with the electronic media and lesser time listening to stories because parents lead such busy lives that they no longer have time to read bed time stories to their children (Talk Talk Group, 2011). Instead they prefer their children to fill their evenings watching the television and playing games (Paton, 2012). Malderez (2010) and Atta-Alla (2012) emphasize on the importance of telling stories and children's literature as a tool in second language. They remark the uses of storytelling as a medium to integrate the communicative skills and activities that afford the collaborative work, encourage student's imaginations, develop language skills, improve listening comprehension, increase vocabulary, enrich students' writing skills and improve social interactions. Similarly, McGrath, Taylor \& Kamen (2004) assert that the use of storytelling with young children support early literacy development and expand the creative literacy potential in young children. Thus, one can see storytelling as a traditional practice and as a pedagogical method that allows the development of all language abilities.

Al-Mansour (2012) investigated the effects of storytelling aloud on the reading comprehension of two groups, one group was controlled and the other was experimential. The experimental group was exposed to storytelling aloud and demonstrated that students achieved better understanding through this method than through the traditional method. Some of the achievements were in regards to better reading comprehension, increase vocabulary and enhancement of communicative skills

Furthermore, Atta-Alla (2012) affirms that by using storytelling, teachers can enhance English language learner' abilities in order to acquire and integrate the four language skills; listening, speaking, reading, and writing in a proficient way.

Similarly, Isbell, Sobol, Lindauer and Lawrence (2004) argue that through storytelling children can improve the development of language and increase story comprehension. They conducted a study to analyze if children are more efficient on comprehension and if they acquire more vocabulary through heard than read stories. Through their research, the authors found the influence of story reading and storytelling on language development. They argue that using story books in story telling increases language learning in children. However, this could be empirically investigated in this study.

Uchiyama (2012) in his study argues that stories also contributed to increase student's acquisition of new vocabulary as they were exposed to listening to stories with a brief explanation of the new words which appeared in them. His research was conducted with 120 Japanese male and female students between 10 and 12 years in public primary school. The researcher made two groups of students who were exposed to English in the last year through games and singing activities. A pre-vocabulary test and a post-vocabulary test were applied to each group, before and after their reading or telling of the story. In his research, Uchiyama used two approaches; the character imagery and the simple reading.

Indeed, storytelling is a method to learn language in context, and it allows to use illustration, linguistic and paralinguistic resources (tone, stress, intonation and rhythm) body language, physical response, and other tools to engage students in understanding stories. This method increases comprehension at the same time students enjoy learning.

This study focus on the effectiveness of storytelling on the reading comprehension and written production of indigenous language (Igbo) learners in primary schools in Ebonyi State, Nigeria.

\section{Purpose of the Study}

The aim of the study was to determine the effectiveness of storytelling on the performance of pupils in reading comprehension and written production in Igbo language in primary schools. Specifically, the study sought to: 
i. Find out the effect of storytelling on mean achievement scores of pupils in reading comprehension in Igbo language.

ii. Determine the effect of storytelling on the mean achievement scores of pupils in written production in Igbo language.

\section{Research Questions:}

1. What are the effectiveness of storytelling on the pupils' mean achievement scores in reading comprehension in Igbo Language?

2. What are the effectiveness of storytelling on the pupils' mean achievement scores in written production in Igbo Language?

\section{Methodology}

This study adopted a pretest-posttest, control group quasi experimental design. Purposive sampling technique was used to select two public primary schools in Ohaozara Local Government Area of Ebonyi State, Nigeria. The sample comprised 100 primary five pupils selected from the two public primary schools. The two schools were randomly assigned to experimental and control group and intact classes were used. Each group consisted of fifty (50) pupils in each of the respective schools.

Instrument for data collection was an achievement test of reading comprehension and indigenous stories. The instruments comprised twenty five (25) items multiple choice with options A-D, each carries one (1) mark and an essay question with 5marks for title, character 5marks,simple plot 5marks, setting 5marks and moral lesson 5marks totaling 25 marks.

The instrument was presented to experts in Igbo language and measurement and evaluation from Ebonyi State University. The experts validated the instruments on the basis of clarity, unambiguousness of words and content coverage. To verify the reliability of the instruments, a pilot test was carried out and reliability coefficient of 0.80 was obtained..

\section{Procedure}

The study lasted for eight (8) weeks. First, three indigenous stories were selected, "Ojaadili"(the great wrestler), "Nwata na Opi ya" (the boy and his flute), and "Otu Mbe siri buru eze umu anumaanu" (how tortoise became the king of the animals). These are stories which usually interest children when they are told. The second week was used to administer the pretest measure on both the experimental and the control groups. Next, the experimental group was exposed to the treatment (storytelling aloud), while the pupils in the control group were taught with the conventional method by their class teacher. Both groups were subjected to post test measure immediately after the treatment. The time interval between the pretest and the post test was eight (8) weeks. The tests were designed and administered by the researcher. Mean scores and standard deviation were used to measure the gain scores of both groups in the pretest and the post test, and to answer the two research questions.

\section{Results}

Research Question I:

What is the effect of storytelling on the pupils' mean achievement score in reading comprehension?

Table 1: Mean and standard deviation of pupil's achievement scores in reading comprehension.

\begin{tabular}{lllllll}
\hline Group & No & $\begin{array}{l}\text { Pretest } \\
\text { Mean }(\mathrm{x})\end{array}$ & $\mathrm{Sd}$ & $\begin{array}{l}\text { Post test } \\
\text { Mean }(\mathrm{x})\end{array}$ & $\mathrm{Sd}$ & Mean gain scores \\
\hline Experimental & 50 & 4.56 & 2.13 & 7.38 & 2.70 & 11.94 \\
Control & 50 & 4.58 & 2.14 & 4.64 & 2.15 & 9.22 \\
\hline
\end{tabular}

Data in table I shows that the mean achievement scores on pupils' achievement in reading comprehension is 7.38 for the experimental group as against 4.64 for the control group when storytelling is used in teaching Igbo language. This means that the pupils in experimental group performed better in reading comprehension than their counterparts in the control group. Similarly, the gain scores between the pretest and the post test scores for experimental and control group were 11.94 and 9.22 respectively. This implies that there is an improvement in pupils' performance in reading comprehension in Igbo language due to the use of storytelling techniques.

\section{Research Question 2:}

What is the effect of storytelling on pupils' mean achievement scores in their written production in Igbo language? 
Table 2: Mean and standard deviation of pupils' achievement scores in their written production in Igbo language

\begin{tabular}{lllllll}
\hline Group & No & $\begin{array}{l}\text { Pretest } \\
\text { Mean }(x)\end{array}$ & Sd & $\begin{array}{l}\text { Post test } \\
\text { Mean }(x)\end{array}$ & Sd & Mean gain scores \\
\hline Experimental & 50 & 4.10 & 1.69 & 7.74 & 3.21 & 11.84 \\
Control & 50 & 3.81 & 1.85 & 4.57 & 2.22 & 8.38 \\
\hline
\end{tabular}

Data in table 2 reveals that the mean achievement scores of pupils' achievement in their written production is 7.74 for the experimental group as against 4.57 for the control group. This shows that students in the experimental group performed better in the written production than those pupils in the control group. Also, the gain scores between the pretest and the post test scores for both the experimental and the control group were 11.84 and 8.38, which implies that there is an improvement in pupils' performance in written production as a result of the storytelling technique used.

\section{Summary of findings}

Based on the data analysis, the following results emerged:

a. Storytelling technique enhances students' reading comprehension in Igbo Language.

b. Storytelling technique improves students' written production in Igbo language.

\section{Discussion of findings}

The analysis of data on the effectiveness of storytelling technique on pupils' reading comprehension in Igbo language revealed that the pupils exposed to storytelling aloud performed better in the reading comprehension ability than their counterparts taught with the conventional method. By comparing the results achieved by the two groups, the researcher reached the conclusion that the improvement achieved by the experimental group may have been attributed to the way they were taught using stories. The storytelling technique used has been a valuable tool to arouse and sustain the pupils' interest and attention which made them to be active participants during the reading process, increased pupils' vocabulary which in turn led to improving comprehension. This in support with Yusuf (2017) who affirms that listening to stories read aloud helped pupils developed healthy listening habits and at the same time paved way to promoting comprehension through consistent exposure to the interesting and meaningful content of the stories.

The data analyzed on the effectiveness of storytelling technique on pupils' written production in Igbo language showed that there is a difference in the mean achievement scores. The pupils exposed to storytelling technique had higher mean scores in written production than those taught with conventional method. The pupils learnt to think creatively and were able to create their own stories. This is in line with Pinzon (2016) that stories are points of reference to improve students writing style.

\section{Conclusion}

The inability of the pupils to read efficiently and fully comprehend a written text in Igbo language was attributed to teacher's monotonous or lack of meaningful activities in reading and writing lessons. Consequently, pupils' participation in Igbo language was limited as well as their learning process. However, in this study it has been established that storytelling is a teaching approach that provide opportunities to improve pupils' reading comprehension and written production in Igbo language. It is the researcher's opinion therefore that Igbo language teachers should employ the use of storytelling to enhance the reading comprehension and written production of learners in Igbo language at the primary school level. This will assist in achieving the curriculum objectives in Igbo at the primary school level.

\section{Acknowledgement}

The Researcher will to appreciate the Staff of the Department of Art and Social Science Education, Ebonyi State University for supplying some of the information used in the work. Also the researcher's appreciation goes to the data analyst for the analysis of the data.

\section{Recommendations:}

Based on the findings, the researcher therefore recommends that;

1. Curriculum planners should include storytelling in the reading and writing components of Igbo language curriculum in the primary schools. Such activities should be made lively, interesting and meaningful.

2. Igbo language teachers should be encouraged to use storytelling technique in the teaching of reading comprehension and written production. This will help to stimulate pupils' interest, build their listening and vocabulary skills. 


\section{References}

Abu Skhela, Kh. (2010). The Effectiveness of using Storytelling Techniques in Enhancing $11^{\text {th }}$ Graders Listening Comprehension Sub - Skills in Middle Gaza Government. Unpublished M. A. Thesis, Gaza: The Islamic University.

Aina, O. (1999). The importance of oral storytelling in literacy development. The Ohio reading teachers 31 (1) $15-18$.

Al-Mansour, N. (2011). The Effect of Teacher's Storytelling aloud on the Reading Comprehension of Saudi Elementary Stage Students. Saudi Arabia, Rhiyadh: King Saud University.

Atta - Alla, M. (2012). Integrating Language Skills through Storytelling. English Language Teaching 5, 1 - 13.

Caulter, C., Michael, C., \& Poyner, L. (2007). Storytelling as pedagogy: an unexpected outcome of narrative inquiry. Curriculum Inquiry 37(2) $103-122$

Comb, M., \& Beach, J. D. (1994). Stories and Storytelling: Personalizing the Social Studies. The Reading Teachers, 47 (6), $464-471$.

Emenanjo, E. N. (1977. ed.) Omalinze: A book of Igbo Folktales. Oxford University press.

Federal Republic of Nigeria (2004; 2014). National Policy on Education. Lagos NERDC Press.

Frisch, J. K., \& Scunders, G. (2008). Using Stories in an Introductory College Biology Course, Journal of Biological Education 42(4) 164 - 169.

Hanaa, I. A. N. (2014). The Effectives of using a storytelling technique on Developing Reading Comprehension Skills for the sixth Graders in Gaza Governorates. M.Ed. Thesis in curricula and Teaching Method. AlAzhar University Gaza.

Harris, R. B. (2008). Blending Narratives: a story telling strategy for Social Studies. Social Studies 98 (3). Pp. $111-116$.

Isbell, R., Sobol, J. Lindaver, Lawrence, A. (2004). The Effects of Storytelling and story reading on the oral language complexity and story comprehension of young children. Early Childhood Education Journal 32(3) $157-163$.

Kosa, J. R. (2008). Tell a story. Education Digest. 74(2), 43 - 47.

Malderez, A. (2010). Stories in ELT: Telling Tales in Schools. Procedia Social and behaviour sciences, 7 - 13.

Mello, R. (2001). The power of storytelling: how oral narratives influences children's relationship in classroom. International Journal of Education and the Art. 2.1.

Mokhtar et al (2010). The Effectiveness of Storytelling in Enhancing Communicative Skills in Foundation Education Course. Centre of General Studies, Malaysia: University Kebangsaan. Available at: www sciencedirect.com

Nwigwe, N. 2016). Oral literature as a springboard for value inculcation to children-British Journal of Education 4(11). $1-10$

Obanya, P. A. I. (2002). Revitalizing education in Africa. Ibadan: Stirling-Horden Publishers Nigeria Ltd.

Oduolowu, E. \& Oluwakemi, A. E. (2014). Effects of storytelling on listening Skills of Primary one pupils in Ibadan, North Local Government Area of Oyo State, Nigeria.

Paton, G., (2012). Parents Shun Bedtime reading in favour of TV Retrieved from http://www.telegraph.co.uk.

Pinzon, M. X. R. (2016). Storytelling and story reading: A way to enhance EFL students' literacies unpublished M. A. Thesis. Bogota-Columbia.

Powell, R. M., \& Murray, O. (2012). Using Storytelling Strategies to improve students comprehension in online classes. The Journal of Effective Teaching, 12(1). 46 - 52.

Satija, M. P., (2002). Reading and book culture. Herald of library science, 41 (1/2), 5 - 59.

TalkTalk Group (2011). New Survey reveals Fears that tradition of reading bedtime stories is dying. Retrieved Nov. 2019. From www.talktalk.co.uk.

Uchiyama, T. (2012). Reading versus telling of stories in the development of English vocabulary and comprehension in young second language learners. Reading Improvement. 48 (4) 168-178.

Yusuf, H. O. (2017)Impact of Teacher's use of folktales on the performance of pupils in reading comprehension in primary schools, in Kaduna State, Nigeria Retrieved http//:www.oapub.org/edu. 